\title{
Zola and the Serial Killer: Robert Black and La Bête Humaine
}

\author{
Adam Lynes, David Wilson* and Craig Jackson
}

\author{
Centre for Applied Criminology, Birmingham City University, England
}

\begin{abstract}
This article presents a critical analysis of Emile Zola's Le Bête Humaine - a critical analysis which forms the basis of a case study of the real-life, British serial killer Robert Black. The fictional character of Jacques Lantier, a train driver living in France in the late $19^{\text {th }}$ century, who is plagued by thoughts of committing murder is compared to Black - a former PDS van driver - who has been convicted of murdering four young girls between 1981 and 1986. The article explores Zola's comments and warnings about the relationship between civilisation and the ever-advancing technology that it creates in order to better the human species or, as is the case of Lantier and Black, for the worse.
\end{abstract}

Keywords: Serial Killer, Modernity, Travelling, Emile Zola, Robert Black, Occupational Choice.

\section{SYNOPSIS}

The issue of travelling and committing murder has been greatly overlooked. This article presents a critical analysis of Emile Zola's Le Bête Humaine and applies that analysis to form a case study of the British serial killer Robert Black. Throughout, the article underscores the importance of travelling - and more generally occupational choice - as central to an understanding of the phenomenon of serial murder.

"It was getting dark and Jacques redoubled his caution. He had seldom known Lison so obedient; he possessed her, rode her as he willed, with the absolute command of the master, yet he never relaxed his severity and treated her like a tamed beast needing constant watching"'

Emile Zola, (1890; Penguin Classics Edition, 1977) Le Bête Humaine.

"I just saw her and got her into the van. I tied her up cos I wanted to keep her until I delivered the parcels to Galashiels. "The detective then asked Black had he touched the girl." It just happened so quick," he said. "I only touched her a little. I wanted to keep her until I went somewhere like Blackpool so I could spend some time with her."

(Court Transcript, Armagh County Court: $7^{\text {th }}$ October 2011)

*Address corresponding to this author at the Centre for Applied Criminology, Birmingham City University, England; Tel: 0121331 5000; Fax: 0121331 6622; E-mail: David.Wilson@bcu.ac.uk

\section{INTRODUCTION}

This article is a case study of Robert Black, a convicted British serial killer. Despite already serving life imprisonment for three other murders, Black was charged and subsequently found guilty in October 2011 of killing nine-year old Jennifer Cardy, thirty years earlier in Ballinderry, County Antrim, Northern Ireland. The basis of this case study is a critical analysis of Emile Zola's novel La Bête Humaine and, in particular, we seek to apply Zola's observation about trains and the railway network to Black's activities. Through analysing the court transcripts from Black's most recent trial for the murder of Jennifer Cardy, we attempt to update Zola's insights, and move his discussion away from railways to roads, and from trains to cars, vans and lorries. For, as Zola - heavily influenced by individual, biological positivism - observes, despite these technological advances, 'there will be wild beasts underneath just the same' (Zola, 1890: 56).

Clearly, the use of a French, late $19^{\text {th }}$ century novel to stimulate insight into an actual case of contemporary British serial murder brings with it inherent dangers (which would warrant an article in themselves), but there are also opportunities which we wish to explore and which we believe are revealed through using this method. We are similarly encouraged that others have also begun to generate more general insights about serial murderers and our fascination with this phenomenon through using literature, TV and film, (Cettl, 2002: 102). We should also make it clear that our intention here is not to engage with the now familiar debates about what is meant when someone is labelled as a serial murderer (Egger, 1990; Hickey, 1996; Holmes and DeBurger, 1988; Jenkins 1994), but rather to see if by taking what Zizek (2007) recently described as a "sideways glance" when looking at violence, new light can be brought to bear on the phenomenon of this type of murder and murderer. Finally, by way of 
introduction, some broad description of Le Bête Humaine is necessary, prior to a more detailed analysis.

Zola (1840-1902), an author famed for his 'naturalistic aesthetic' (Bloom, 2004: 1), wrote La Bête Humaine in 1889 and the novel itself was published the following year. This seventeenth novel out of the twenty that forms Zola's Rougon-Macquart cycle is often considered one of his 'most violent and pessimistic novels' (Tancock, 1977: 7). The story is a tense, psychological thriller set alongside the railway line between Paris and Le Havre and takes place at the twilight of the $19^{\text {th }}$ century. The main characters are Roubaud, the deputy station master at Le Havre, his wife Séverine, who, upon first inspection, is seemingly innocent and naïve of the world she inhabits, and Jacques Lantier, the quiet and introverted train driver. Lantier works on the Paris to Le Havre railway line and is the link - due to family - with the other characters in Zola's Les Rougon-Macquart series. La Bête Humaine tackles multiple themes, including the fashionable - at the time - individual positivist approach to criminal behaviour, which suggested that 'the abnormal and the dangerous could be recognised and mapped in physical space and evolutionary time' (Morrison, 2004: 67 ), and was made popular by the Italian criminologist Cesare Lombroso (Muncie, 2001: 212-213). The novel's final prominent theme was the nature of the railway system which, for Zola embodied the unrelenting pace of advancements in industry. However, it is Zola's almost prophetic description of man's interrelated relationship with mechanics and machines that stirs and evokes the most, especially in relation to today's serial killers, and provides the backdrop to this case study, (Zola, 1890: 56).

We use the character Jacques Lantier from La Bête Humaine, as a means to try to understand Robert Black. However, it is acknowledged that it is important to differentiate fact from fiction, and although Zola's novel is indeed dark and disturbing there is one significant difference between Lantier and the real-life serial killer Robert Black. This difference stems from their different motivations to become involved in an occupation that required moving from place to place, and rarely stopping in one particular location for too long. For Lantier, his entire life had been dominated by the need to run away from the voices in his head forever tempting him to kill young women - whereas Black used his mobility as the means by which he would be able to repeatedly kill. This comparison brings to attention another important facet of this case study, which is the underlying theme of determinism which stems from Zola's novel. While individual positivism is impossible to escape from within this case study, it is also important to acknowledge the authors do not endorse a deterministic explanation of serial murder and will be critical, where necessary, of this approach.

\section{LANTIER AND BLACK}

In an introduction to the novel, written by the translator Leonard Tancock, Lantier is described as being:

"No simple maniac, but a tragic figure pursued by destiny, aware of his own fatal flaw of character, who struggles against it but is ultimately overtaken by his doom"' (Tancock, 1977: 14).

This statement evokes themes reminiscent of the time, where the creation of the 'Newgate' novel in the 1820s focused on portraying the typical 'villains' as both romantic and sympathetic, (Burney, 2012). Lantier's work as a respectable engine driver - even if he was also harbouring a desire to commit crime - was also part of a common trend of the latter half of the $19^{\text {th }}$ century, which shifted focus from the more typical lower-class criminals to the more respectable middleclass (Wiener, 1990). However, in the grand scheme of Zola's novel, Lantier is not the only character in this haunted and pessimistic world to hide feelings and thoughts of murder. In fact, the majority of the characters seem to be plagued by desires and lusts to kill another human being, though each for very different reasons. Zola, while writing La Bête Humaine, was influenced by a striking, and at the time thought provoking theory:

"Love and death, possessing and killing, are the dark foundations of the human soul'” (Zola, 1890).

Some of this can be attributed to Zola's witnessing of the incredible and seemingly swift, industrial revolution that was taking place across Europe (Hanagan, 1999: 204), and he uses La Bête Humaine as a critical commentary of the quickly evolving world surrounding him. The above quote, which would eventually become synonymous with La Bête Humaine, is Zola's attempt to remind us that, despite these incredible feats of industry, we are all ultimately still at the mercy of our natural instincts. This is further amplified by the inclusion of multiple and interrelated 
storylines, such as Roubaud, the jealous husband, and the free spirited yet agitated Flore - each exhibiting different forms of aggression towards other individuals, which conveys to the reader the notion that we are all susceptible to these feelings that form the dark foundations of the human soul'. Tancock (1977) elegantly summarises Zola's pessimistic view on humanity, regardless of what technological advances we may achieve:

'"Zola can let the reader watch several quite different types of murder: the man who kills in a blind rage of sexual jealousy, the cold, slow, poisoner after his victim's money, the psychopath whose decent, reasonable side struggles in vain against his hereditary predisposition, and various sub-species such as the woman maddened by passion or jealousy or the man with a grievance turned into a brute by alcohol."' (Tancock, 1977: 13).

La Bête Humaine attempts to cover and analyse many different themes: from the intimacy of sex to the wider, societal issue of politics and corruption. Zola also wants to inform his audience about the social conditions, and inequalities of the time (Pakulski, 2004: 16) through the intimate, and human, portrayal of his characters. Thus Lantier is, in many ways, the embodiment of the best and worst of humanity. Here is a man who is most comfortable at the helm of one of humanity's greatest technical triumphs - a train, his beloved "La Lison" - and as such he comes to represent modernity and advancement into the new century. Tragically, he also possesses the very qualities and traits that, if they had the chance, would prevent this industrial and technological evolution from taking place and ultimately take us back to a less enlightened period in time.

Robert Black can be viewed as Lantier come to life. However, not for him a train but a van, which he used to deliver advertising posters across the United Kingdom. Black would be categorised by Holmes and DeBurger (1998: 10) as a 'geographically transient serial killer' - in other words someone who continually travelled during the course of their killing spree - which is an issue which we discuss more fully below. This particular type of serial killer differs from the 'geographically stable serial killer' in that, due to the nature of travelling over a large geographical area, the transient serial killer is likely to attack and kill a victim in one particular police jurisdiction before moving on, and repeating a similar offence in another police jurisdiction. This ability to gain access to different areas and committing murder makes the task of connecting these offences to the same offender difficult, as it creates what is known as 'linkage blindness' (Keppel and Birnes, 2003: 3) between the various police services involved. So, unlike Lantier, Black used his van - his mobility - for very different reasons, and in particular as a means and as a place where he could make his fantasies become real. He was not so much running away from his fantasies, but instead finding a way to make them come to life.

\section{THE SERIAL KILLER AND MODERNITY}

Since the publication of La Bête Humaine motor vehicles have become the most common means of transport and drastically changed the world that Zola was commenting upon. Not only has the significance of trains dwindled with the arrival of cars, vans and lorries, but a new breed of criminal has also taken centre stage - the serial killer. Haggerty (2009) has recently discussed how the "serial killer" is a social construct, and that this construction is inextricably linked with modernity:

The rise of such modernizing processes over a comparatively long time frame of several hundred years set the parameters of what it means to be a serial killer, and established the preconditions for serial murder to emerge in its distinctive contemporary guise, (Haggerty, 2009: 171).

Haggerty notes that there 'six important preconditions for serial killing which are distinctively modern' (ibid: 173). These factors include the evergrowing attention on celebrity culture; a society full of unfamiliar faces in our day to day lives; a means to an end rationale that is often detached from values such as morality; a society that permits the ability to draw attention to a particular social group resulting in greater chances of 'predation'; weaknesses in society's structure which leads to victimisation; and, finally, the belief that society is 'engineered' (ibid: 173). Haggerty's argument regarding the moving away from the dominant "medico-psychological perspective" (ibid: 169) and instead focusing on social issues within a modern context shares similar viewpoints with the other prominent theoretical perspective about serial killing, labelled the "structural approach", (Wilson, 2009: 2). 
Seltzer (1998) also offers an understanding of this phenomenon, noting that serial murder holds its own, unique, position in a society in which compulsive acts of brutality have not only gathered a shared fascination, but are also one of the only places where personal yearning and public desire meet and interact. An example of this would be either the "stampede" of members of the public when enticed by a possible scene of violence and chaos, or waiting around a crime scene in the hope of seeing a mutilated body, (Seltzer, 1998: 1). Interestingly, Zola also explores this phenomenon. The character Flore, for example, who works near the railway line, is described as being intensely fascinated to discover the remains of an accident, to such an extent that she receives emotional satisfaction upon discovering another unfortunate individual near the railway tracks:

"Flore was standing there, looking too. She loved accidents: any mention of an animal run over, a man cut in pieces by a train, was bound to make her rush to the spot"' (Zola, 1890: 74).

Here, Zola provides an example of what Seltzer would alter call the 'body-machine complex' (Seltzer, 1998: 63). This concept involves our creation and use of machinery in order for us to be more efficient in several different aspects of our lives, including areas such as 'medical interventions to make us live better...vehicles to make us move faster... and weapons so we can kill better', (Gray, 2004: 179). Machines have indeed improved our quality of life, although there is a flipside to this body-machine relationship, as these very machines can also be used for more malevolent purposes. In regards to Flores' reaction to the news of a train accident, this intense fascination with mutilated bodies as a result of machinery has been explored and elaborated on in other, more contemporary literature. For example, J. G. Ballard's controversial novel Crash (1973) is a story about symphorophilia, or car-crash sexual fetishism, in which its protagonists become sexually aroused by staging and participating in real car-crashes. This fixation with technology, violence and sexual gratification even leads the sinister character of Dr. Robert Vaughan to fantasize about dying in a head-on collision with movie star Elizabeth Taylor. Other literary texts have also explored this 'body-machine complex', but with a more science fiction undercurrent. Novels such as Asimov's Robot Series - namely I, Robot (1950) and Naked Sun (1957) - along with Philip K. Dick's Do Androids Dream of Electric Sheep (1968) tackle the questions that may one day be asked when machines become more and more sophisticated and intelligent, and which may further complicate this 'bodymachine' relationship.

This notion has not only been restricted to literature, with similar themes being explored in films such as The Invisible Boy (1957), Colossus: the Forbin Project (1970), and the Terminator movies (1984-2009). Each of these films centre on humanity's creations ultimately turning on their creators - often with devastating consequences. There have also been relatively recent cases of accidents involving industrial robots which have led to profound questions such as who is to blame? With so many parties involved including the $\operatorname{victim}(\mathrm{s})$, the operators, the programmers, and the robot, where does the responsibility and culpability fall? Thus the fictitious Jacques Lantier and real-life Robert Black are examples of how this body-machine relationship can be used to not only make us more efficient in moving from one location to another more rapidly, but also much more effective in killing another human being(s).

Seltzer claims that the serial killer is "one of the superstars of the Wound Culture," (Seltzer, 1998: 2) and Haggerty notes that this type of murderer is "readymade for prime time," (Haggerty, 2009: 174). As these quotes suggest, the question as to what makes an individual commit horrendous crimes against other human beings is clearly one which has caught the public's imagination and curiosity. Why should this be the case? One possible explanation may be the media's portrayal of serial killers, but also crime fiction novels regularly use serial killers as characters who look like us, yet are capable of such extreme acts of violence that they evoke feelings of disgust and wonder. This fascination with the macabre and the unknown also shares similarities with other forms of media, such as science fiction so that serial killers can be viewed as travellers from another time and space, (Doris, 2010: 9). In short, that they seem to hold up a mirror to mankind revealing the worst that we are capable of. Despite none of the characters in La Bête Humaine actually being a serial killer, it is Lantier's use of Lison that we wish to use to throw further light onto the activities of Robert Black.

\section{THE CASE OF ROBERT BLACK}

Robert Black is a British serial killer who originated from Stirlingshire in Scotland. Black, who had access to a van due to his occupation as a poster delivery man, 
killed four young girls from 1981 till 1986 and was eventually apprehended in a failed attempt to abduct another young girl in 1990. His modus operandi (MO) included snatching "his young victims off the streets as they played, or walked to and from their homes," (Wilson, 2007: 150). Black seems to have sporadically selected the locations in which he attacked his victims. For example, Jennifer Cardy was abducted in County Antrim, Northern Ireland, while his second known victim - eleven-year old Susan Maxwell - was taken by the van driver near the village of Cornhill on Tweed, on the English side of the English/Scottish border, as she walked to play a game of tennis across the border. A little under a year later in 1983, Black's third known victim, five-year old Caroline Hogg, left her home in Portobello, an eastern suburb of Edinburgh, to play in the near-by playground. She never returned home. Black's final victim that we know about - ten-year old Sarah Harper - was abducted almost three years after Caroline. Sarah lived in Morley, Leeds and was kidnapped by Black as she made her return trip home from the corner shop.

The case of Jennifer Cardy went unsolved until 2011. The investigation into her abduction and murder was left open for twenty-eight years and it was only in 2005 that the case was revisited, (McDonald, 2011). The prosecution, which took place in County Armagh, Northern Ireland, described in detail Black's MO which involved the use of his work delivery van, noting that the van was integral to his abduction of his victims, (Court Transcript: $7^{\text {th }}$ October 2011). Throughout the five-week trial, it became clear that, while the van proved to be an invaluable tool for Black in order to commit his crimes, it would also ultimately lead to his downfall and conviction for Jennifer's murder. The prosecution in particular drew attention to key evidence that proved that Black's delivery van was close to the area in which Jennifer's body was found, thus implicating Black in her abduction:

The Crown has also argued that petrol purchases made on the day after the murder demonstrate that Black was in Northern Ireland the previous day (Court Transcript: $7^{\text {th }}$ October 2011).

It is apparent that the use of his van was the most important aspect of Black's MO, and also the most important element of building a case against him. Through an analysis of the court transcripts, we are offered an insight into how Black used his van in order to commit his offences, and all of this can be compared and contrasted with how Lantier used his train.

\section{LA BÊTE HUMAINE AND ROBERT BLACK}

While Lantier is the protagonist of La Bête Humaine, it is Aunt Phasie who poses the most relevant philosophical question at the heart of this case study. Described by Zola as being 'barely forty-five...formerly so tall and buxom, looked more like sixty, shrunk and sallow and shaken by constant spasms' (Zola, 1890: 51 ), in another age Aunt Phasie might well have been accused of practicing witchcraft, (Hester, 1996: 290). This 'shrunk and sallow' woman who has aged beyond her actual years does indeed seem to possess knowledge unavailable to the other characters, and therefore offers prophetic warnings to the reader. Aunt Phasie, for example, informs Lantier, who is himself torn between his morally good side and the more sinister yet seductive side, that no matter how advanced mankind becomes, there is no escape from the primeval nature in us all:

"Oh, it's a wonderful invention [the railway], you can't deny it...People travel fast and know more...But wild beasts are still wild beasts, and however much they go on inventing still better machines, there will be wild beasts underneath just the same"' (Zola, 1890: 56).

Thus Zola - through Aunt Phasie - poses the crucial question: as we continue to invent 'better machines', do we as a species evolve along with them, or will they simply continue to mask our true primal nature and urges that we, along with Lantier, are continually attempting to run away from? Black's case provides us with a means to answer this question, even if the answer to that question was at odds with how Zola attempted to resolve it 120 years earlier.

Zola was evidently influenced by the work of Cesare Lombroso. Indeed Zola, through his literary creations, is considered to have improved these theories (Burney, 2012). Lombroso believed that criminals were biologically different from the average, law abiding citizen and destined to commit crime, (Carrabine, et al., 2008: 61). This radical, at the time, theoretical perspective can clearly be witnessed in the character of Lantier. Zola was not only supportive of Lombroso's perspective on why individuals committed crime, but also in how such behaviour should be approached. So Aunt Phasie informs the reader of Lantier's abnormalities, and the steps that they had taken to "cure" him, asking Lantier: 
"You remember back home the things you suffered from that the doctor couldn't make out at all?...It's all gone, that pain you used to get in the head, behind the ears, and those sudden temperatures and fits of depression that made you hide away like an animal in its den?"' (Zola, 1890: 56).

Zola through this individual, biological, positivist approach, attempts to create a sympathetic and tragic character in Lantier who, despite his best efforts to outrun his destiny, was unable to escape the clutches of his true, deviant behaviour. There have been, both before and after the time of Zola, countless examples of the notion of seemingly innocent human beings concealing something quite sinister and dangerous. For example; from a psychoanalytic perspective, Sigmund Freud's "id" clearly conveys the concept of humanity's battle against more primal instincts. The "id" is the disordered part of the personality construction which encloses our basic compulsions. The "id" is said to also contain the sex drive, which is the primary source of instinctual energy that is indifferent to the needs of reality. The "id" acts in order to fulfil the "pleasure principle", seeking to avoid pain or discontentment aroused by increases in instinctual strain (Weiten, 2007).

This concept, albeit portrayed in a simpler form, can be seen in William Shakespeare's The Tempest (1623), in which the character of Caliban, a native of the island on which Prospero, and the protagonist of the narrative, lands after being usurped by his brother Antonio. Caliban, similar to Lantier, is portrayed as being a man clearly afflicted by a compulsion to commit carnal urges whilst also displaying a love for creativity and the arts. For example; Caliban tries to rape Miranda, Prospero's daughter who was also situated on the island but, in stark contrast, Caliban also has a capacity for poetry and understanding beauty, as shown by a speech in Act III, which is considered to be one of the most poetic, beautiful, and evocative of the play (Hansens, 2003). Another literary example of such inner turmoil can be found in Robert Louis Stevenson's Strange Case of Dr. Jekyll and Mr. Hyde (1886) in which the protagonist of the novel, Dr Jekyll, a "large, well-made, smooth-faced man of fifty", sporadically suffers from a battle between the good and evil that exists within himself, consequently leading to a conflict between his dual personalities of $\mathrm{Dr}$ Jekyll and $\mathrm{Mr}$ Hyde. He has spent a great part of his life attempting to suppress his evil compulsions that were not appropriate for a man of his stature and position in Victorian society. He concocts a potion in an endeavour to remove this hidden evil within his personality. However, in doing so Jekyll is transformed into the slimmer, younger, but also cruel, callous, evil Edward Hyde. While there are indeed many literary examples of seemingly innocent people harbouring, in secret, "evil" intentions, Stevenson's novel, due to being published only four years before Zola's Le Bête Humaine, resonates the most with Jacques and his own private battle between the "good" and "evil" of his personality.

On the other hand it is quite clear that, in the case of Robert Black, this positivist approach in itself cannot explain his actions. He is anything but a tragic figure attempting to outrun, or escape from some preordained destiny. Instead, it is evident that rather than attempting to run away from his secret desires and needs, he was in fact pursuing them:

"I only touched her a little. I wanted to keep her until I went somewhere like Blackpool so I could spend some time with her" (Court Transcript: $7^{\text {th }}$ October 2011).

In the above statement - which was shown to the jury when Black's offending history was revealed to them for the first time - there is evidence of the premeditation with regard to what he was going to do once he had abducted his victim. This premeditation and planning starts from the abduction of his victims, and only ends when the fantasy of committing the act is complete. At this point, as Black has stated, he would '"Just let her go, drop her off"', though, of course, there is a deeper, more sinister, meaning to this statement. Black did not simply drop them off; instead he would kill his victims before dumping their bodies in an often remote location. In the case of Jennifer Cardy, for example, 'in a dam behind a roadside lay by 15 miles away at Hillsborough' (Rayner, 2011). Indeed, he went as far as not only using his transport as a way of moving his victims from the scene of their abduction, but also incorporated it as part of his "fantasy space", (Wilson and Jones, 2008: 107). It was in his van that Black felt most comfortable in exploring and developing his fantasies. However, Black has rarely spoken about his crimes (and also pleaded not guilty to Jennifer's murder), and so it is difficult to be too precise about what actually took place in his van and when he had total control over his victim(s). However, we can gain some insight into what actually took place through the 
simple description given at the Cardy trial of how Mandy Wilson was discovered:

"Mr Hedworth told the silent courtroom that when Black, who worked as a poster Delivery driver, was arrested in Stow, the six-year-old girl was found stuffed in to a sleeping bag in the back of his van"' (Court Transcript: $7^{\text {th }}$ October 2011).

Mandy - who survived this attack - was being kept alive so that Black could spend longer with her later and when, it could be argued, he would have more time to be alone with her and indulge his fantasies. In many respects his van became his home - a private space where guests were abducted, rather than invited into.

Here we are seeing two very similar individuals both trying to cope with their dark desires and fantasies with the aid of transport, though with very different results. Consider, for example, these two quotes:

"I saw the driver get out and open the bonnet of the engine...then he shouted 'Can you fix engines?'...I suddenly felt the man grab me from behind... I think he said something like 'Get in you bitch,' as we were struggling" (Wyre, Tate, 1995).

"He possessed her, rode her as he willed, with the absolute command of the master, yet he never relaxed his severity" (Zola, 1890: 158-159)

The first is a segment from a testimony given by one of Black's victims - Teresa Ann Thornhill - who luckily managed to survive her encounter with the serial killer, while the second is a description of Lantier and his behaviour towards Lison. Both reveal how these men interpret the use of a vehicle, and how both the fictitious Lantier and very real Black are, in fact, more different than alike. While there are evident similarities in regards to both men's relentless need for possession and control, the fact that Lantier channels this aggression towards his train while Black chooses to focus this need onto his victims through using his van as a lure, signifies the somewhat stark differences between the fictitious world that Lantier inhabits, and the reality that Black exists within.

Whether a train or a van, Lantier and Black's vehicles act as not only a means to control their thoughts or to pursue them, but also becomes their homes. For an offender, especially those involved in serial offending, their base - the place in which they return to after committing their offences - is also often their home. And, as David Canter is quick to point out, this base "can take various forms...it can become a haven or even a den into which he brings his victims. In some cases it is a moving location, even a vehicle', (Canter, 2005: 11).

\section{HAVING A BASE}

This description of the importance of a base clearly applies to both Lantier and Black, though in different degrees. For Lantier his base is indeed "Lison", his beloved train. Zola discusses how Lantier rarely spends any of the little free time he has at his apartment. Instead, he is described as being "only in love with his engine...forever polishing her, making her shine as if you (Lantier) had no endearments for anybody but her," (Zola, 1890: 63). For Lantier, the need for unwavering attention in both working on his train, and driving it, acts as a diverter in regards to his hidden desires and fantasies. Zola emphasises this early in the novel, going into intimate detail into how Lantier acts and thinks around a young women, and when away from his beloved train:

"'His heart began to pound, and he suddenly felt that he was the one she was waiting for, and with the blood being pumped into his head there rose a terrible disquiet...some madness seemed to be taking possession of him, some ferocity making him cast his eyes for a weapon"' (ibid: 63-64).

Without Lison, with all its mechanical components keeping Lantier's mind occupied, he clearly struggles in keeping his 'ferocity' at bay. While Lantier is at the helm of Lison, which is implied by Zola as being for much of his time due to 'the oil staining his mechanic's hands' (ibid: 50), he is able to keep away from potentially fatal interactions. Aunt Phasie reinforces this notion of Lantier attempting to run away from something, mentioning to Lantier that '....and I look out for you on your engine. Only you go so fast, so very fast!'(ibid: 55). For Lantier, there is evidently a preference for mechanics as opposed to human interaction and calmness seems to come from the cold, detached process of repairing machines and driving them. In comparing his behaviour while with his train, to his behaviour away from 'her', there are notable differences. He is described by Zola as being 'happy, calm and away from the world' (ibid: 68) while with 
Lison, whereas 'involuntary' shuddering at the sight of a woman while away from his train (ibid: 50 ).

Black, when compared to Lantier, more accurately fits Canter's description in regard to the significance of a base. While Lantier uses his base to run away from his fantasies, Black, it could be argued, instead uses this base to pursue them. Here we have an interesting contrast. Both men suffer from the internal motivation to commit serious offences, but each use their vehicles, or their base, in very different ways. Both Lantier and Black enjoy the solitary nature of their jobs, as for Lantier it means he would not be tempted by the sights of women which would result in his urges rising. Black, on the other hand, preferred the solitude as it lessened the risk of any potential witnesses to his crimes:

"It was a rush of blood. I've always liked young girls since I was a young kid." The officer asked him if he worked alone. "It's not the sort of thing you do with witnesses around, is it?" Black replied. "I just saw her and got her into the van. I tied her up cos I wanted to keep her until I delivered the parcels to Galashields," (Court Transcript: $7^{\text {th }}$ October 2011).

The above account, which gives insight into why Black may have chosen the profession that he did, conveys the sheer difference between him and Lantier with regard to their motivations to work with vehicles. It is apparent that, for Black, his van was his 'own world', a place where he felt safe and capable of "thinking, dreaming, imagining and fantasising without fear of constraint from normality or reprimand from the real world," (Wilson \& Jones, 2008: 107). While Lantier uses Lison, otherwise referred to as his 'own world', to repress his fantasies, Black actually exploits his very private space to fulfil his fantasies. Wilson and Jones reinforce this notion of fantasies preceding offending, noting that 'the fantasy space provides the motivation for offending. Within this space sexual fantasies are "initiated, replayed and mental imagery relating to the fantasy is constructed," (ibid: 111). For Black, his fantasy space and his physical space were intertwined. His van, while acting as his safe haven in order to escape the realities of every-day life, also acted as a trigger for igniting his latent fantasises that had no place in the civil society that surrounded him. Not only does working by himself result in a much lower risk of there being any witnesses to his crimes, but it also results in the ability to dream, imagine, and fantasise without the fear of external judgement against him.
Lantier, on the other hand, judges himself. This can be witnessed with his interaction around his cousin - Flore - where Zola describes in some detail Lantier's moral conflict:

"Oh God, so this horrible affliction he thought he was cured of had come back again, had it? He had really tried to kill this girl! Kill a woman, kill a woman, that had buzzed through his ears since his earliest adolescence"' (Zola, 1890: 65).

Interestingly, Lantier does not fulfil his fantasies at this point in the novel. Instead, in a state of panic and confusion he, seemingly by accident, ends up near the rail way line (ibid: 70). Zola again reinforces the significance of trains for Lantier as, when all hope seems to be lost for him in keeping his 'beast at bay', a train's lights fills the tunnel ahead of him like 'a door of a furnace full of blazing wood' (ibid: 70), shining like a beacon for his sanity to follow. In order for Lantier to escape from this internal conflict and consequently the harsh judgment he inflicts upon himself, he turns to his train. Both men are attempting to escape forms of judgment, but while Black is hiding himself away from other people and therefore external judgement, Lantier is instead trying to repress his own internal judgement by not placing himself near external triggers - young women.

For both Lantier and Black, the way in which they viewed and connected to their vehicles went through a transformation of sorts. There is a pivotal scene in the novel where the young Lantier, who is tired and disoriented due to running away from Flore who triggered his repressed impulses, witnesses a violent murder on a train. This scene is not only the catalyst for the rest of the novel, but also acts as a trigger in Lantier's psyche in terms of his control over his hidden desires. Lantier 'quite distinctively saw through the lit cape' and witnessed a man "holding another man down on the seat and plunging a knife into his throat," (ibid: 70). This single act of extreme violence, which is seemingly over before it began, taints what was once a sanctuary for Lantier, and a way for him to hide away from his ever-tempting thoughts and desires. Immediately after witnessing this brutal murder, one of Lantier's first thoughts is not of sadness or pity towards the victim but rather envy towards the perpetrator:

"What he had merely dreamed about the other man had done it, and there it was. If he were to kill, there it would be, on the 
ground. His heart was beating furiously and his itch for murder intensified like a physical lust"' (ibid: 73).

Lantier, despite being described as being 'extremely intelligent', consciously wanted to become a train driver for the "solitude and oblivion he found in it," (ibid: 68). The events that transpired the night he witnessed the murder on the train though, deformed his perception of the very place he sought comfort and peace from. His base, his beloved train Lison, no longer is the place that Lantier can turn to in order to escape his growing desire to kill another person and instead it has become the very thing in his life that seems to be actually encouraging this repressed side to his personality. In response, Lantier becomes very agitated and aggressive towards what he once considered to be his safe haven. For example, while making a routine journey between stations, he cannot help but notice that something about Lison was different from the norm. Lantier notes that there is 'something vague and deep-seated that he never felt before, a sort of anxiety and mistrust of her, as though he could not quite trust her' (ibid: 156). While this may refer in part to the way in which Lison was operating as a piece of machinery, it is also arguable that this new found uneasiness was not actually Lison at all, but rather represented something happening to Lantier as a result of what he witnessed, and who is in fact transferring his new perception of trains, or specifically Lison onto the machine. The witnessing of the brutal and macabre murder, which only lasted for a few brief seconds, would ultimately destroy Lantier's support structure, resulting in him being plagued with more and more compulsions to kill.

Does technology repress the "beast within", or instead allow it to be expressed? There have been some interesting suggestions seeking to provide an answer. William F. Ogburn's theory of "cultural lags", in which Ogburn suggests that cultural innovations lag after technological innovations, is one such example. According to Ogburn, cultural lag is a general societal occurrence due to the propensity of material culture to develop and change rapidly and voluminously, while non-material culture appears to refuse to accept change and remains fixed for a much longer period of time. As a result of these contrasting natures, adaptation of new technology becomes relatively difficult (Ogburn, 1922). A modern example of cultural lag can be found in the internet and cyberspace. It has been argued that this new technology has resulted in the creation of a conduit that has been, and is currently, being used by certain individuals to express their "beast within" (Paxson, 2004).

An interesting literary example of such a theme can be found in George Orwell's Nineteen Eighty-Four (1949) - a dystopian novel about Oceania, a society ruled by the oligarchical dictatorship of the Party. Life in the Oceanian province of Airstrip One is a world of perpetual war, pervasive government surveillance, and incessant public mind control. Here we have an example of technology, while being used by the ruling bodies, to control the general public for their own malevolent purposes; conveying the notion that it is not just individuals, but also groups that share a common interest or ideologies that may use machines to fulfil their morally questionable ambitions. This concept of factions of people using technology to better express their more "savage" tendencies has been a subject of debate for war historians. John Keegan's A History of Warfare (1993), Victor David Hanson's Carnage and Culture: Landmark Battles in the Rise of Western Power (2001) and John A. Lynn's Battle: a History of Combat and Culture from Ancient Greece to Modern America (2003) have all deliberated the idea of how technological advancements have slowly industrialised humanity's ability to kill. While this topic may appear odd in a discussion regarding a real-life serial killer and a fictitious murderer; it would be premature to dismiss the concept of technology and war, where mass killing is taken place thanks, in part, to humanity's invention of machines and continuously improving technology.

\section{FANTASY AND REALITY}

While for both Lantier and Black, the transport that they use and ultimately emotionally attach to was a product of their occupation, this is where the similarities end. For Black, the van which he used to deliver posters may have first started as a means to fantasise. For example, in his trial Black, who denied the charges put before him, was reported to say the following when questioned by Police about his fantasies:

"l'd be driving along and see a young girl," he said. "l'd get out and talk to her and try to persuade her to getting into the van and take her somewhere quiet." The police officer asked what would happen if the girl refused to go with him. "In your fantasies that doesn't happen," Black said in his head the girl would not resist his subsequent sexual advances in the back of the van (STV, 2011). 
Like Lantier, he could have found comfort in the 'solitude and oblivion' (ibid: 68) that the van offered. More instrumentally, the use of a vehicle, especially to those, like Black, who drive as part of their profession, offers them a valid reason for being alone for long periods of time and to be left alone with their thoughts and consequently their fantasies. However, as is often the nature for serial murder, these fantasies are no longer enough:

Eventually, the individual will actually act on the fantasy. At this point the serial killer engages in a series of progressively more accurate "trial runs" in an attempt to enact the fantasy as it is imagined, (Bartol and Bartol, 2004: 144).

When compared to Lantier, who uses "Lison" to prevent him from committing murder, Black instead uses his van as a means to commit murder. The van, for Black, was his private space where he could fantasise as he journeyed from one location to another, and the action of forcing his victims into this very personal space demonstrates that his fantasies incorporated his van. This is displayed by his surviving victim Thornhill, who emphasised that Black not only attempted to lure her to him by asking for assistance with the van's engine, but also his desire to get her inside the van, "get in you bitch" (Wyre and Tate, 1995: 116-117).

Black was not only physically trying to get Thornhill into his van, he was also trying to make her enter the space where he, as discussed earlier, fantasised about offending and for her to ultimately become an important component of this very private, intimate world. With regards to Black's choice of vehicle, it is possible that it was a conscious decision to have access to transport with more free space than regular road vehicles. Whether or not he consciously chose the profession that he did in order to have access to such a vehicle in order to commit his crimes is also of interest, but it may be that Black become more dependent and attached to his van as his killing cycle developed.

When comparing the fictitious Lantier to a real life serial killer - described as being "every parent's worst nightmare," (Reid, 2008), there are similarities, but also distinct differences. Lantier slowly learned to rely on Lison to help to keep his internal demons at bay, until the point at which he suffers anxiety attacks when away from her. Black, on the other hand, came to rely on his van for different psychological reasons, using the space it provided to instead encourage his private thoughts and fantasies till the point at which that very same space would become the vital component that he needed in order to live out these growing desires. Both men depend heavily on their vehicles; both rely on their transport to physically move them from place to place; they both also used their different forms of transport as a means to escape the world around them, either to rein control over their fantasies, or to give them life.

\section{CONCLUSION}

There has been almost no scholarly research about the relationship between serial killing and driving as an occupation. Even so, it is clear that a significant number of British serial killers were employed as drivers of some sort. The most notable example in Britain would be Peter Sutcliffe - otherwise referred to as the "Yorkshire Ripper" - who was convicted of killing thirteen women and attacking seven others between 1975 and 1980. And, as the name given to him by the press implies, the bodies of his victims were often mutilated, (Wilson, 2007: 77). Sutcliffe committed all of his crimes with the aid of transport. Not only did he drive various cars in order to carry out his crimes but, like Black, he also consciously chose a profession which allowed him to be surrounded by other vehicles (and mechanics) in a work culture where there was little managerial control exercised over his movements, (Bilton, 2003: 730). Other examples of these geographically transient serial killers in Britain include Fred West, who, with the aid of his wife Rose, would pick up lone young women walking along roads before taking them back to the now demolished 25 Cromwell Street, (Newton, 2000: 281); Peter Tobin, the Scottishborn serial killer who worked as an odd-job man, and who would bury his victims in his back garden before relocating to a new area, (Tran, 2010). We might also cite the former ship's steward and fork-lift truck driver Steve Wright who, as with Sutcliffe, picked up prostitutes in his car before killing them, stripping them of their clothes and dumping their bodies in and around the town of Ipswich, (Addley, McVeigh, Batty, 2008). Most recently we have had the case of Levi Bellfield an ex-bouncer and wheel clamper - often referred as the "Bus Stop Killer" (Wansell, 2011). Bellfield would follow his victims while he was in one of his many cars, before exiting and attacking them, often with a blunt object. In the case of one of his surviving victims - Kate Sheedy - Bellfield actually used his vehicle as a weapon, by attempting to run Ms Sheedy over, (Edwards, 2008). 
Clearly there are significant differences between how individuals kill in works of fiction as opposed to those who kill in reality. This is not intended to criticise Zola's portrayal of a man plagued by homicidal thoughts, but instead we have used his writing to shed light on, and discuss the author's perception of the complex and ever changing relationship that mankind has with vehicles and their links to murder. While it would be wrong to generalise to all known serial killers who used a vehicle in order to commit their offences, this "sideways glance" at Black and his use of a van is an example of Zola's warning about the idea of "progress" in civilization. While Zola, a man of his time, encapsulated his warning around Lombroso's discredited positivist approach, the general theme should not be ignored. Namely, that despite all of our technological accomplishments and the striving for more efficient machines, we are still fallible. For some, like Lantier, a vehicle can act as a form of transport to escape the problems of the real world. For others, their vehicles permit them to enter another world - a world constructed by their fantasies - so much so that for a small, select few such as Robert Black, that they will ultimately take these fantasies and turn them into reality. Like the tragic Lantier, we may try to outrun and escape from this repressed side we all possess, but no matter how advanced or fast our inventions become, we may never truly be free from the 'wild beast' within us, (Zola, 1890: 56).

\section{ACKNOWLEDGEMENT}

The authors would like to acknowledge Danielle Bishop for her invaluable advice and support.

\section{REFERENCES}

Asimov, I. (1950) I, Robot, New York, Panther

Asimov, I. (1957) The Caves of Steel, New York, Harper Collins

Ballard, J. G. (1973) Crash, London, Vintage

Bartol, C., R., Bartol, A., M. (2004) Introduction to Forensic Psychology, London, Sage publications

Bilton, M. (2003) Wicked Beyond Belief: the Hunt for the Yorkshire Ripper, London, HarperCollins Publishers

Burney, E. (2012) 'Crime and Criminology in the Eye of the Novelist: Trends in Nineteenth Century Literature', The Howard Journal, Vol. 51, No. 2, May, pp. 160-172 http://dx.doi.org/10.1111/j.1468-2311.2011.00703.x

Canter, D. (2005) Mapping Murder: Walking in Killer's Footsteps, London, Virgin Books

Cameron, J. (1984) The Terminator, UK: 20th Century Fox Home Entertainment

Cameron, J. (1991) Terminator 2: Judgment Day, UK: $20^{\text {th }}$ Century Fox Home Entertainment

Carrabine, E., Lee, M., Plummer, K., South, N., Iganski, P. (2004) Criminology: A Sociological Introduction, London, Routledge
Cettl, R. (2002) Serial Killer Cinema, London, McFarland \& Co Inc

Dick, K. D. (1968) Do Androids Dream Of Electric Sheep?, London, Millennium

Doris, J., M. (2010) 'Foreword', in: S. Waller ed. 2010. Serial Killers: Being and Killing Philosophy for Everyone, West Sussex, Blackwell Publishing Ltd, pp. Viii- Xi

Douglas, J., Olshaker, M. (1996) Mindhunter: Inside the FBI's Elite Serial Crime Unit, New York, Pocket Books

Douglas, J. (1998) Obsession, London, Pocket Books Ltd

Douglas, J. (1997) Journey Into Darkness, London, Pocket Star books Ltd

Egger, S., A. (1990) Serial Murder: An Elusive Phenomenon, Westport, Praeger Publishers

Grover, C., Soothill, K. (1997) 'British Serial Killing: Towards a Structural Explanation', British Society of Criminology, Vol. 2, July, pp. 1-17

Haggerty, K., D. (2009) 'Modern Serial killers', Crime, Media, Culture, Vol. 5, No. 2, pp. 168-187 http://dx.doi.org/10.1177/1741659009335714

Hansens, J. (2003) Caliban - his Representation in Shakespeare's "The Tempest" and Three Film Versions, Munich, GRIN Publishing

Hanson, V. D. (2001) Carnage and Culture: Landmark Battles in the Rise of Western Power, New York, First Anchor Books

Hester, M. (1996) 'Patriarchal Reconstruction and Witch Hunting', in: J. Barry, M. Hester, G. Roberts, ed. 1996, Witchcraft in early modern Europe: studies in culture and belief, Melbourne, Cambridge University Press, pp. 288-309

Hickey, E., W. (1996) Serial Murderers and Their Victims, London, Brooks/Cole Publishers

Hoffman, H. (1957) the invisible boy, [online] Available at: http://www.youtube.com/watch?v=Yn2BF-xtWD8 [accessed $5^{\text {th }}$ June 2012]

Holmes, R., DeBurger. J. (1988) Serial Murder. Newbury Park, CA: Sage Publications

Jenkins, P. (1994) Using Murder: The Social Construction of Serial Homicide. New York, Transaction Publishers

Keegan, J. (1993) a History of Warfare, London, Pimlico

Keppel, R., D., Birnes, W., J. (2003) The Psychology of Serial Killer Investigations: The Grisly Business Unit, London, Academic Press

Lynn, J. A. (2003) a History of Combat and Culture from Ancient Greece to Modern America, Boulder, Westview Press

Mostow, J. (2003) Terminator 3: Rise of the Machines, UK: Sony Pictures Home entertainment

Michaud, S., G., Aynesworth, H. (1983) The Only Living Witness: The True Story of Serial Sex Killer Ted Bundy, London, Authorlink Press

Misselbrook, D. (2010) 'The General Practitioner and Abuse in Primary Care', in: F. Subotsky, S. Bewley and M. Crowe, ed. 2010. Abuse of the Doctor Patient-Relationship, London, The Royal College of Psychiatrists, pp. 78-91

Morrison, W. (2004) 'Lombroso and the Birth of Criminological Positivism: Scientific Mastery or Cultural Artifice?', in: J. Ferrell, K. Hayward, W. Morrison, M. Presdee, ed. 2004. Cultural Criminology Unleashed, London, Glasshouse Press, pp. 67-81

Muncie, J (2001) 'Positivism', in: E. McLaughlin and J. Muncie ed. (2001) The Sage Dictionary of Criminology, London, Sage Publications, pp. 212-214

Nelson, B. (2004) Emile Zola: The Kill, Oxford, Oxford University Press

Nichol, J. M. (2009) Terminator: Salvation, UK: Sony Pictures Home entertainment 
Ogburn, W. F. (1922) Social Change with Respect to Culture and Original Nature, New York, B.W. Huebsch

Orwell, G. (1949) Nineteen Eighty-Four, London, Penguin Books

Paxson, P. (2004) Media Literacy: Thinking Critically About The Internet, Portland, Walch Publishing

Reid, M. (1995) 'Child killer Robert Black to be Charged Over Two More Murders from Decades Ago', The Times Online, [Online] $11^{\text {th }} \quad$ April. Available at: http://www.timesonline.co.uk/tol/news/uk/crime/article372420 7.ece [Accessed 23rd November 2011]

Sargent, J. (1970) Colossus: the Forbin project, UK: Medium Rare

Seltzer, M. (1998) Serial Killers: Death and Life In America's Wound Culture, London, Routledge

Shakespeare, W. (1623) The Tempest, Oxford, Oxford University Press

Stevenson, R. L. (1886) The Strange case of Dr. Jekyll and Mr. Hyde, London, Penguin Books

'Robert Black trial hears of killer's sex fantasies', STVU, [online] available at: http://news.stv.tv/scotland/275232-robert-blacktrial-hears-of-killers-sex-fantasies/ [accessed 25/07/2012]
Tancock, L (1977) 'Introduction', La Bête Humaine, Emile Zola (1890) Middlesex, Penguin Books Ltd

Weiten, W. (2007) Psychology: Themes \& Variations, Belmont, Thomson Higher Education

Wiener, M (1990) Reconstructing the Criminal: Culture, Law and Policy in England, 1830-1914, Cambridge, Cambridge University Press

Wilson, D., Jones, T. (2008) 'In My Own world: A Case Study of a Paedophile's Thinking and Doing and His Use of the Internet', The Howard Journal, Vol. 47, No. 2, pp. 107-120 http://dx.doi.org/10.1111/j.1468-2311.2008.00512.x

Wilson, D. (2007) Serial Killers: Hunting Britons and Their Victims 1960-2006, Winchester, Waterside Press

Wilson, D. (2009) A History of British Serial Killing, London, Sphere

Wyre, R., Tate, T. (1995) The Murder of Childhood, London, Penguin Books Ltd

Zola, E. (1890) La Bête Humaine, Middlesex, Penguin Books Ltd

Received on 08-07-2012

Accepted on 01-08-2012

Published on 03-10-2012

DOI: http://dx.doi.org/10.6000/1929-4409.2012.01.6

(C) 2012 Lynes et al.; Licensee Lifescience Global.

This is an open access article licensed under the terms of the Creative Commons Attribution Non-Commercial License (http://creativecommons.org/licenses/by-nc/3.0/) which permits unrestricted, non-commercial use, distribution and reproduction in any medium, provided the work is properly cited. 